\title{
Vietnam's position in ASEAN economic community (AEC) through the analysis of global competitiveness index (GCI)
}

- Nguyen Chi Hai

- Tra Van Trung

University of Economics and Law, VNU HCM - Email: hainc@uel.edu.vn

(Bài nhận ngày 22 tháng 6 năm 2016, hoàn chỉnh sủa chũa ngày 14 tháng 3 năm 2017)

\begin{abstract}
The Global Competitiveness Index (GCI) is a reliable basis to evaluate the level and competency of innovation and development of economies. The objective of this research is to analyze Vietnam's GCI in comparison with the countries in ASEAN Economic Community (AEC) in order to "locate" the economic position of Vietnam in the region. The result of the research shows that (i) There is an equivalence relation between the GCI and
\end{abstract}

economic position of Vietnam in AEC; (ii) The limitations of Vietnam GCI are just the causes of the limitations and laggings in the current economy of Vietnam; (iii) The breakthrough for the development of Vietnam economy, shortening the economic gap of Vietnam among the countries in AEC, is necessary to have solutions to improve the competitiveness of economy.

Key words: The economic position of Vietnam in AEC; The Global Competitiveness Index of Vietnam

\section{INTRODUCTION}

Vietnam, a country with S-shape, had no name in the world map until before 1945 and was just the place belonging to Indochina controlled by France. On 2 September, 1945 at Ba Dinh Square, Hanoi president Ho Chi Minh read the Proclaimation, announcing the birth of the Democratic Republic of Vietnam. From 1945 to 1975 Vietnamese people faced the 2 wars with the French and American. At that time, Vietnam's economy grew in the war stage, serving war efforts with serious destructions. After the liberation of South (30 April, 1975), the whole country was unified and built up Socialism. In the period 1975
1985, Vietnam's economy developed sluggishly and laggardly in comparison with the countries' in the area while its economic model was running with limitations and unsuitability. The reform of economic thoughts and model applied in the late 1986 by the Communist Party and Government of Vietnam created a good premise and condition to help Vietnam's economy overcome "low-income trap" (2010) and Vietnam becomes a lower middle income country. And the desire of Vietnam is to early achieve industrialization and modernization to become a prosperous nation in 2035. 
The desire to become a prosperous nation of Vietnamese people has become very usual for a lot of generations. To make the desire come true, first of all we have to answer the important questions: (i) What's Vietnam's position in Southeast Asia and the world?, (ii) What goals will Vietnam gain in the next $15-$ 20 years?, (iii) What path and measure will make these goals come true?

At the development potential, Vietnamese people are optimistic about their country and themselves, especially Vietnamese intelligence and culture which have been formed for thousands of years of history. Once Lee Kuan Yew (Ly Quang Dieu), who is famous and knowledgeable about Vietnam, visited the country and stated, "If there is a number 1 position in Southeast Asia, it must be worth belonging to Vietnam. Because of advantages of geo-politics, natural and human resources, Vietnam cannot rank after any nation in the area." (Cam Ha, January 16, 2007). This statement is reasonable by a person of vision like Lee Kuan Yew. More importantly, the statement helps us have a lot of thoughts which must need answers to the first question: What's Vietnam's position in Southeast Asia and the world?

In the current context of globalization, indicators of national rankings in the world are becoming more and more diverse. However, in the comprehensive norm, the Global Competitiveness Index (GCI) by the World Economic Forum (WEF) is used popularly and has fairly high availability.

In this paper, we will answer the $1 \mathrm{st}$ question 'What's Vietnam's position in AEC via GCI?', giving some comments to improve Vietnam's position in the future.

\section{LITERATURE REVIEW}

The Global Competitiveness Report is the annual report published by the World Economic Forum, giving GCI assessments, including determinants of the productivity of an economy and prosperiority of a nation in comparison with other nations in the area and the world.

GCI consists of twelve pillars of competitiveness with 113 variables relevant to major sectors of an economy. The twelve pillars of competitiveness are divided 3 groups:

Basic requirements includes

Institutions); (ii) Infrastructure; (iii) Macroeconomic environment); (iv) Health and primary education.

Efficiency enhancers include (i) Higher education and training; (ii) Goods market efficiency; (iii) Labor market efficiency; (iv) Financial market development; (v) Technological readiness; (vi) Market size.

Innovation and sophistication factors include: (i) Business sophistication; (ii) $\mathrm{R} \& \mathrm{D}$ Innovation.

Based on the official statistics and practical survey, weighted scoring method and formula application for each country, the GCI score is a scale of 1 to 7 . The weights of three groups of pillars are $60 \%, 35 \%$ and $5 \%$, which shows the importance of each group in the assessment of the WEF.

Besides GCI, to assess the national competitiveness, economic organizations use Indices of Economic Freedom, Doing Business and Ease Doing Business. However, GCI guarantees a comprehensive assessment, reflecting dynamic and competitive capacities among nations. 


\section{RESEARCH METHODOLOGY AND DATA}

Firstly, synthetic and analytical methods used in this research are based on the secondary data and GCI by the World Economic Forum. The data resource is updated from the Global Competitiveness Report 2016 - 2017 and the previous years of the WEF. The relevant information and data are also used for the research analysis. Next, logical and systematic approaches will be used to give conclusions and recommendations.

\section{RESEARCH FINDINGS}

\subsection{An introduction on Vietnam's position in AEC}

Association of Southeast Asian Nations (ASEAN) was set up in 1967, comprising 10 member states in Southeast Asia, where economies develop fairly dynamically. ASEAN covers a land area of 4,435,670 square kilometres with the population of approximately 598,498,000 people, the GDP of $1,850.855$ billion USD and the total trade of 2,042.788 billion USD. The ASEAN Economic Community (AEC) was officially formed on 31 December, 2015. AEC is one of ASEAN's important 3 pillars, aiming at carrying out the given goals in ASEAN vision 2020 (The remaining pillars are ASEAN Political-Security Community and ASEAN Socio-Cultural Community). The following 4 characteristics are also the 4 factors forming AEC (i) A single market and production base; (ii) A highly competitive economic region; (iii) Equitable economic development and (iv) Integration in Globalised Economy.

Table 1. An overview on Vietnam's economy in AEC

\begin{tabular}{|c|l|r|r|r|}
\hline No & Counties & $\begin{array}{c}\text { Population } \\
\text { (million) }\end{array}$ & \multicolumn{2}{|c|}{ GDP } \\
(billion USD) - 2015 & GDP per capita (USD - 2015) \\
\hline 1 & Brunei & 0.4 & 11.8 & $28,236.6$ \\
2 & Cambodia & 15.5 & 18.2 & $1,168.0$ \\
3 & Indonesia & 255.5 & 12.5 & $3,362.4$ \\
4 & Laos & 7.0 & 296.2 & $1,778.7$ \\
5 & Malaysia & 31.0 & $62.8\left(^{*}\right)$ & $9,556.8$ \\
6 & Myanmar & 292.0 & $1,221\left(^{*}\right)$ \\
7 & Philippines & $1.4(*)$ & 292.7 & $2,858.1$ \\
8 & Singapore & 3.5 & $52,887.8$ \\
9 & Thailand & 68.8 & 191.5 & $5,742.3$ \\
10 & Vietnam & 91.7 & & $2,088.3$ \\
\hline
\end{tabular}

Source: The Global Competitiveness Report 2016 - 2017

Vietnam's land area ranks 4th in Southeast Asia (After Indonesia, Myanmar and Thailand). However, its GDP ranks 6th in the region (After Indonesia, Thailand, Malaysia, Singapore and Philippines). Vietnam's GDP per capita ranks 7 th, which is higher than Cambodia, Laos and Myanmar. According to the WEF's data 2015, GDP per capita of Vietnam is equal to $3.9 \%$ of Singapore, $7.4 \%$ of Brunei, 21.8\% of Malaysia. 36.4\% of Thailand, $62 \%$ of Indonesia and $73 \%$ of Philippines. In comparison with the period before "đổi mới" (1986), GDP per capita of Vietnam improves considerably, shortening the 
gap among ASEAN nations, however, the gap is still rather big. In the WEF's ranking about the economic position with 3 development

Table 2. Countries/economies at each stage of development

\begin{tabular}{|l|l|l|l|}
\hline & $2014-2015$ & $2015-2016$ & $2016-2017$ \\
\hline \multirow{4}{*}{ Stage 1: Factor-driven } & Cambodia & Cambodia & Cambodia \\
\cline { 2 - 4 } & Laos & Laos & Laos \\
\cline { 2 - 4 } & Myanmar & Myanmar & \\
\cline { 2 - 4 } & Vietnam & & \\
\hline \multirow{3}{*}{ Sransition from stage 1 to stage 2 } & Philippines & Philippines & Philippines \\
\cline { 2 - 4 } & & Vietnam & Vietnam \\
\hline \multirow{2}{*}{ Stage 2: Efficiency-driven } & Indonesia & Indonesia & Indonesia \\
\cline { 2 - 4 } & Thailand & Thailand & Thailand \\
\cline { 2 - 4 } & Timor-Leste & & \\
\hline Stage 3: Innovation-driven & Malaysia & Malaysia & Malaysia \\
\hline
\end{tabular}

Source: The Global Competitiveness Report 2016 - 2017

The country classification, according to development stages, exactly reflects the positions of economies in the area as well as GDP per capita and economic efficiency. Since levels, Vietnam is between transition stages 1 and 2 along with Philippines (Table 2).

\subsection{The global Competitiveness Index}

Table 3. The GCI of Vietnam and AEC

\begin{tabular}{|l|l|l|l|l|l|l|l|l|l|l|l|}
\hline \multirow{2}{*}{ No } & \multirow{2}{*}{ Country } & \multicolumn{2}{|c|}{$2012-2013$} & \multicolumn{2}{c|}{$2013-2014$} & \multicolumn{2}{c|}{$2014-2015$} & \multicolumn{2}{|c|}{$2015-2016$} & \multicolumn{2}{c|}{$2016-2017$} \\
\cline { 3 - 11 } & & Score & Rank & Score & Rank & Score & Rank & Score & Rank & Score & Rank \\
\hline 1 & Brunei & 4.9 & $28 / 144$ & 4.9 & $26 / 148$ & & & & & 4.3 & $58 / 138$ \\
2 & Cambodia & 4.0 & 85 & 4.0 & 88 & 3.9 & $95 / 144$ & 3.9 & $90 / 140$ & 4.0 & 89 \\
3 & Indonesia & 4.4 & 50 & 4.5 & 38 & 4.6 & 34 & 4.5 & 37 & 4.5 & 41 \\
4 & Laos & & & 4.1 & 81 & 3.9 & 93 & 4.0 & 83 & 3.9 & 93 \\
5 & Malaysia & 5.1 & 25 & 5.0 & 24 & 5.2 & 20 & 5.2 & 18 & 5.2 & 25 \\
6 & Myanmar & $\mathrm{n} / \mathrm{a}$ & $\mathrm{n} / \mathrm{a}$ & 3.2 & 139 & 3.2 & 134 & 3.3 & 131 & $\mathrm{n} / \mathrm{a}$ & $\mathrm{n} / \mathrm{a}$ \\
7 & Philippines & 4.2 & 65 & 4.3 & 59 & 4.4 & 52 & 4.4 & 47 & 4.4 & 57 \\
8 & Singapore & 5.7 & 2 & 5.6 & 2 & 5.6 & 2 & 5.7 & 2 & 5.7 & 2 \\
9 & Thailand & 4.5 & 38 & 4.5 & 37 & 4.7 & 31 & 4.6 & 32 & 4.6 & 34 \\
10 & Vietnam & 4.1 & 75 & 4.2 & 70 & 4.2 & 68 & 4.3 & 56 & 4.3 & 60 \\
\hline
\end{tabular}

Source: The Global Competitiveness Report 2016 - 2017 
According to the WEF's Global competitiveness Report 2016 - 2017, Vietnam gets $4.3 / 7$ points, ranks 60 th out of 138 countries participating in the survey and drops 4 places in comparison with the Report 2015 2016. However, its sore is unchangeable and the number of countries surveyed last year was 140. In the period 2015 - 2016, Vietnam's GCI improved very well when climbing 12 places (56th ranking out of 140 countries) in comparison with the Report 2014 - 2015. Since the period 2007 - 2008, Vietnam's GCI has remarkably improved, increased 0.3 points (4.0 up to 4.3 ) and just been 0.5 points less than Cambodia (3.5 up to 4.0) and 0.4 points less than Philippines (4.0 up to 4.4). This improvement shows Vietnam's efforts in enhancing its business environment and raising the activeness of its economy. However, Vietnam's GCI has a lower level and a further gap than the nations' in the region. With the Report 2016 - 2017, among the surveyed countries in Southeast Asia (except for TimorLeste and Myanmar), Vietnam's score is equal to Brunei's (4.3), higher than Laos (3.9), Cambodia (4.0) and a lot lower than Singapore (5.7), Malaysia (5.2), Thailand (4.6). In the global ranking of competitiveness, Vietnam ranks 60th out of 138 surveyed countries, is higher than Laos (93rd ranking) and Cambodia (89th ranking), is nearly equal to Brunei (58th ranking), Philippines (57th ranking), and is very far from Singapore (2nd ranking), Malaysia (25th ranking), Thailand (34th ranking), Indonesia (41st ranking). Vietnam's limitations about competitiveness assessed by international organizations and economic experts are because the Government controls inefficiently, the macroeconomic policy is unstable, the trained labor force do not meet the requirement, the labor discipline is bad, and the corruptions have no signs of improvement.

\subsection{Basic requirements}

Basic requirements reflect basic factors of an economy, such as Institutions, Infrastructure, Macroeconomic environment and Health and primary education. This is just Vietnam's group of indicators scoring the highest in comparison with the remaining two groups. However, its ranking is at the lowerhalf position in the ranking list of the WEF (73rd ranking). The table 4 shows Vietnam's scores and rankings in the recent years.

Table 4. Vietnam's scores and rankings in Basic requirements

\begin{tabular}{|l|c|c|c|c|c|c|c|c|c|c|}
\hline & \multicolumn{2}{|c|}{$2012-2013$} & \multicolumn{2}{c|}{$2013-2014$} & \multicolumn{2}{c|}{$2014-2015$} & \multicolumn{2}{c|}{$2015-2016$} & \multicolumn{2}{c|}{$2016-2017$} \\
\cline { 2 - 10 } & Score & Rank & Score & Rank & Score & Rank & Score & Rank & Score & Rank \\
\hline Basic & 4.2 & $91 / 144$ & 4.4 & $86 / 148$ & 4.4 & $79 / 144$ & 4.5 & $72 / 140$ & 4.5 & $73 / 138$ \\
requirements & & & & & & & & & & \\
- Institutions & 3.6 & 89 & 3.5 & 98 & 3.5 & 92 & 3.7 & 85 & 3.8 & 82 \\
- Infrastructure & 3.3 & 95 & 3.7 & 82 & 3.7 & 81 & 3.8 & 76 & 3.9 & 79 \\
$-\begin{array}{l}\text { Macroeconomic } \\
\text { environment }\end{array}$ & 4.2 & 106 & 4.4 & 87 & 4.7 & 75 & 4.7 & 69 & 4.5 & 77 \\
$-\begin{array}{l}\text { Health and } \\
\text { primary } \\
\text { education }\end{array}$ & 5.8 & 64 & 5.8 & 67 & 5.9 & 61 & 5.9 & 61 & 5.8 & 65 \\
\hline
\end{tabular}

Source: The Global Competitiveness Report 2016 - 2017 
In the recent years, Vietnam's Basic requirements have considerably improved both scores and rankings. However, the criteria of this group have been at the second-half positions in the ranking list. Only a quarter of these criteria, which are Health and primary education, have got the first-half position in the ranking list. Yet this position seems to be unchangeable. In general, Vietnam's indicators of Basic requirements can be identified more fully.

Table 5. AEC's Basic requirements 2016-2017

\begin{tabular}{|c|c|c|c|c|c|c|c|c|c|c|c|}
\hline \multirow[t]{2}{*}{ No } & \multirow[t]{2}{*}{ Country } & \multicolumn{2}{|c|}{$\begin{array}{l}\text { Basic } \\
\text { requirements }\end{array}$} & \multicolumn{2}{|c|}{ Institutions } & \multicolumn{2}{|c|}{ Infrastructure } & \multicolumn{2}{|c|}{$\begin{array}{c}\text { Macroeconom } \\
\text { ic } \\
\text { environment }\end{array}$} & \multicolumn{2}{|c|}{$\begin{array}{l}\text { Health and } \\
\text { primary } \\
\text { education }\end{array}$} \\
\hline & & Score & Rank & Score & Rank & Score & Rank & Score & Rank & Score & Rank \\
\hline 1 & Brunei & $4.8 / 7$ & $50 / 13$ & 4.2 & 47 & 3.9 & 78 & 4.9 & 61 & 6.3 & 31 \\
\hline 2 & Cambodia & 4.2 & 8 & 3.5 & 104 & 3.2 & 106 & 5.0 & 50 & 5.2 & 103 \\
\hline 3 & Indonesia & 4.8 & 96 & 4.1 & 56 & 4.2 & 60 & 5.5 & 30 & 5.3 & 100 \\
\hline 4 & Laos & 4.2 & 52 & 4.0 & 68 & 3.1 & 108 & 4.3 & 87 & 5.2 & 102 \\
\hline 5 & Malaysia & 5.5 & 99 & 5.0 & 26 & 5.4 & 24 & 5.4 & 35 & 6.1 & 44 \\
\hline 6 & Myanmar* & 3.5 & 26 & 2.9 & 133 & 2.1 & 134 & 4.2 & 106 & 4.6 & 113 \\
\hline 7 & Philippines & 4.6 & 128 & 3.6 & 91 & 3.4 & 95 & 5.9 & 20 & 5.6 & 81 \\
\hline 8 & Singapore & 6.4 & 65 & 6.1 & 2 & 6.5 & 2 & 6.1 & 11 & 6.7 & 2 \\
\hline 9 & Thailand & 4.9 & 1 & 3.7 & 84 & 4.4 & 49 & 6.1 & 13 & 5.5 & 86 \\
\hline 10 & Vietnam & 4.5 & $\begin{array}{l}44 \\
73\end{array}$ & 3.8 & 82 & 3.9 & 79 & 4.5 & 77 & 5.8 & 65 \\
\hline
\end{tabular}

Source: The Global Competitiveness Report 2016 - 2017

Table 5 shows (i) Singapore has the best score about indicators which reflect Basic requirements of its economy and ranks the highest in the world. These indicators have been maintained for many years and their improvement levels have risen, (ii) Malaysia, Brunei, Thailand and Indonesia have scores and rankings with good and fairly good levels. Among these countries, Malaysia is the most outstanding and enters top $20-30$ in the global competiveness list, (iii) The group of 5 countries which have scores and rankings with fair and low levels includes Philippines (4.6; 65), Vietnam (4.5; 73), Cambodia (4.2; 96), Laos (4.2; 99) and Myanmar (3.5; 128), in which Vietnam's ranking is nearly equal to
Philippines' and far higher than the remaining 3 countries.

In Institutions, the Report 2016 - 2017 indicates that Vietnam gets 3.8 points and ranks $82^{\text {nd }}$ out of 138 countries participating in the survey. This is better than last year (3.7 points; $85^{\text {th }}$ ranking). However, in the periods from 2010 - 2011 to 2016 - 2017, Vietnam's Institutions improvement is low and unstable. In the Report 2010 - 2011, Vietnam's Institutions got 3.8 points and ranked $74^{\text {th }}$. In the following years, these indicators went down (2011 - 2012: 3.6 points, $87^{\text {th }}$ ranking; $2012-$ 2013: 3.6 points, $89^{\text {th }}$ ranking; $2013-2014: 3.5$ points, $98^{\text {th }}$ ranking; $2014-2015$ : 3.5 points, 
$98^{\text {th }}$ ranking) and have enhanced in the recent years. In AEC, Vietnam's Institutions ranking is higher than Cambodia's (3.5 points; $104^{\text {th }}$ ranking), Philippines' (3.6 points; $91^{\text {st }}$ ranking) and Thailand (3.7 points; $84^{\text {th }}$ ranking), but lower than Laos' (4.0 points, $68^{\text {th }}$ ranking), Indonesia's (4.1 points; $56^{\text {th }}$ ranking), Brunei's (4.2 points; $47^{\text {th }}$ ranking), and a lot lower than Singapore's (6.1 points; $1^{\text {st }}$ ranking), Malaysia's (5.0 points; $26^{\text {th }}$ ranking). In the recent 2 years, Vietnam's efforts to reform administration and build up "tectonic government" have enabled the Institutions to improve better; yet a numerous factors related to the entrepreneur law, economic monopoly, corruptions, etc. have been happening and improved slowly. Therefore, the Institutions are the "blocking points" in the economic development in Vietnam.

In Infrastructure, in the recent years Vietnam has clearly been acknowledged about its efforts and progress in developing infrastructure, especially transportation, telecommunications, energy. In the Report 2012 - 2013, Vietnam's Infrastructure only got 3.3 points and ranked $95^{\text {th }}$ out of 144 surveyed countries; got 3.7 points and ranked $82^{\text {nd }}$ out of 148 surveyed countries from 2013 to 2014; got 3.7 points and ranked $81^{\text {st }}$ out of 144 surveyed countries from 2014 to 2015 ; got 3.8 points and ranked $76^{\text {th }}$ out of 140 surveyed countries from 2015 to 2016; got 3.9 points and $79^{\text {th }}$ out of 138 surveyed countries from 2016 to 2017. However, Vietnam's infrastructure quality is a lot lower than the countries in the area, such as Indonesia, Thailand, Singapore, and Malaysia. In reality, the infrastructure condition is also the 'blocking point' in Vietnam's economic development, especially traffic jams, quality of railways, airports, ports, etc. have a big influence on life and investment attraction.

In Macroeconomic environment, Vietnam is also acknowledged about its efforts in macroeconomic stability for the sustainable development after the $11^{\text {th }}$ National Party Congress (2011). The WEF's Report shows that Vietnam got 4.2 points and ranked $106^{\text {th }}$ out of 144 surveyed countries from 2012 to 2013; got 4.4 points and ranked $87^{\text {th }}$ out of 148 surveyed countries from 2013 to 2014; got 4.7 points and ranked $75^{\text {th }}$ out of 144 surveyed countries from 2014 to 2015 ; got 4.7 points and ranked $69^{\text {th }}$ out of 140 surveyed countries from 2015 to 2016; got 4.5 points and ranked $77^{\text {th }}$ out of 138 surveyed countries from 2016 to 2017. Thus Vietnam's macroeconomic stability indicators improved, but have had the trend of leveling off and gone down in the recent 2 years. Compared with the countries in the region, Vietnam's stable indicator of macroeconomic environment is higher than Myanmar's (4.2 points; rank $\left.106^{\text {th }}\right)$, Laos' (4.3 points; rank $108^{\text {th }}$ ) and lower than the remaining countries, even Cambodia.

Health and primary education is Vietnam's best criterion in comparison with other criteria. This criterion gets 5.8 points and ranks $65^{\text {th }}$ out of 138 surveyed countries in the period 2016 2017. In AEC, Vietnam is only lower than Singapore (6.7 point; $2^{\text {nd }}$ ranking) and Malaysia (6.1 points; $44^{\text {th }}$ ranking). Actually, in the recent years, this criterion has not improved, even decreased within 2016 and 2017. In the Report 2012 - 2013, Vietnam's Health and primary education got 5.8 points and ranks $64^{\text {th }}$ out of 144 surveyed countries; got 5.8 points and ranked $67^{\text {th }}$ out of 148 surveyed countries from 2013 to 2014; got 5.9 points and ranked $61^{\text {st }}$ out of 144 surveyed countries from 2014 to 2015; got 5.9 points and ranked $61^{\text {st }}$ out of 138 surveyed countries from 2015 to 2016; gets 5.8 points and ranks $65^{\text {th }}$ out of 144 surveyed countries from 2016 to 2017 (decreases 4 positions). Vietnam's limitations are relevant to 
facilities of medical system, quality of Health and primary education.

\subsection{Efficiency enhancers}

Efficiency enhancers fully reflect the factors affecting the efficiency enhancement of the economy, have the causality with Basic requirements at the higher level and correspond with the $2^{\text {nd }}$ development stage according to the WEF's Global Competitiveness Ranking. To assess Vietnam's position in the ranking list and compare with other nations in the region, we can see the following $6^{\text {th }}$ and $7^{\text {th }}$ tables:

Table 6. Vietnam's scores and rankings in Efficiency enhancers

\begin{tabular}{|c|c|c|c|c|c|c|c|c|c|c|}
\hline & \multicolumn{2}{|c|}{$2012-2013$} & \multicolumn{2}{|c|}{$2013-2014$} & \multicolumn{2}{|c|}{$2014-2015$} & \multicolumn{2}{|c|}{$2015-2016$} & \multicolumn{2}{|c|}{$2016-2017$} \\
\hline & Score & Rank & Score & Rank & Score & Rank & Score & Rank & Score & Rank \\
\hline $\begin{array}{l}\text { Efficiency } \\
\text { enhancers }\end{array}$ & 4.0 & $71 / 144$ & 4.0 & $74 / 148$ & 4.0 & $74 / 144$ & 4.0 & $74 / 140$ & 4.1 & $65 / 138$ \\
\hline $\begin{array}{l}\text { 1- Higher } \\
\text { education and } \\
\text { training }\end{array}$ & 3.7 & 96 & 3.7 & 95 & 3.7 & 96 & 3.8 & 95 & 4.1 & 83 \\
\hline $\begin{array}{l}\text { 2- Goods market } \\
\text { efficiency }\end{array}$ & 4.1 & 91 & 4.3 & 74 & 4.2 & 78 & 4.2 & 83 & 4.2 & 81 \\
\hline $\begin{array}{l}\text { 3- Labor market } \\
\text { efficiency }\end{array}$ & 4.5 & 51 & 4.4 & 56 & 4.4 & 49 & 4.4 & 52 & 4.3 & 63 \\
\hline $\begin{array}{l}\text { 4-Financial } \\
\text { market } \\
\text { development }\end{array}$ & 3.9 & 88 & 3.8 & 93 & 3.8 & 90 & 3.7 & 84 & 3.9 & 78 \\
\hline $\begin{array}{l}\text { 5- Technological } \\
\text { readiness }\end{array}$ & 3.3 & 98 & 3.1 & 102 & 3.1 & 99 & 3.3 & 92 & 3.5 & 92 \\
\hline 6- Market size & 4.6 & 32 & 4.6 & 36 & 4.7 & 34 & 4.8 & 33 & 4.8 & 32 \\
\hline
\end{tabular}

Source: The Global Competitiveness Report 2016 - 2017 
Table 7. AEC's Efficiency enhancers 2016 - 2017

\begin{tabular}{|c|c|c|c|c|c|c|c|c|c|c|c|c|c|c|c|}
\hline \multirow[t]{2}{*}{ No } & \multirow[t]{2}{*}{ Country } & \multicolumn{2}{|c|}{$\begin{array}{l}\text { Efficiency } \\
\text { enhancers }\end{array}$} & \multicolumn{2}{|c|}{$\begin{array}{c}\text { Higher } \\
\text { education and } \\
\text { training }\end{array}$} & \multicolumn{2}{|c|}{$\begin{array}{l}\text { Goods market } \\
\text { efficiency }\end{array}$} & \multicolumn{2}{|c|}{$\begin{array}{l}\text { Labor market } \\
\text { efficiency }\end{array}$} & \multicolumn{2}{|c|}{$\begin{array}{c}\text { Financial market } \\
\text { development }\end{array}$} & \multicolumn{2}{|c|}{$\begin{array}{l}\text { Technological } \\
\text { readiness }\end{array}$} & \multicolumn{2}{|c|}{ Market size } \\
\hline & & Score & Rank & Score & Rank & Score & Rank & Score & Rank & Score & Rank & Score & Rank & Score & Rank \\
\hline 1 & Brunei & 3.9 & 87 & 4.5 & 65 & 4.3 & 68 & 4.5 & 47 & 3.7 & 92 & 3.6 & 84 & 2.7 & 116 \\
\hline 2 & Cambodia & 3.7 & 97 & 2.9 & 124 & 4.2 & 76 & 4.4 & 58 & 4.1 & 63 & 3.3 & 98 & 3.3 & 86 \\
\hline 3 & Indonesia & 4.4 & 49 & 4.5 & 63 & 4.4 & 58 & 3.8 & 108 & 4.3 & 42 & 3.5 & 91 & 5.7 & 10 \\
\hline 5 & Malaysia & 5.0 & 24 & 5.0 & 41 & 5.2 & 12 & 4.8 & 24 & 5.0 & 13 & 4.8 & 43 & 5.0 & 24 \\
\hline 6 & Myanmar (*) & 3.2 & 131 & 2.5 & 134 & 3.6 & 130 & 4.2 & 73 & 2.4 & 138 & 2.2 & 138 & 4.2 & 60 \\
\hline 7 & Philippines & 4.2 & 58 & 4.6 & 58 & 4.1 & 99 & 4.0 & 86 & 4.2 & 48 & 3.6 & 83 & 4.9 & 31 \\
\hline 8 & Singapore & 5.7 & 2 & 6.3 & 1 & 5.8 & 1 & 5.8 & 2 & 5.7 & 2 & 6.1 & 9 & 4.7 & 37 \\
\hline 9 & Thailand & 4.6 & 37 & 4.5 & 62 & 4.7 & 37 & 4.2 & 71 & 4.4 & 39 & 4.3 & 63 & 5.2 & 18 \\
\hline 10 & Vietnam & 4.1 & 65 & 4.1 & 83 & 4.2 & 81 & 4.3 & 63 & 3.9 & 78 & 3.5 & 92 & 4.8 & 32 \\
\hline
\end{tabular}

Source: The Global Competitiveness Report 2016 - 2017 
In the Report 2016 - 2017, Vietnam's Efficiency enhancers get 4.1 points, rank $65^{\text {th }}$ out of 138 surveyed countries, and increase 0.1 point, $9^{\text {th }}$ position in comparison with the period $2015-2016$. Yet this indicator is equal to the indicator of the period $2011-2012$ (4.1 points; $66^{\text {th }}$ ranking) and lower than the indicator of the period $2010-2011$ (4.2 points; $57^{\text {th }}$ ranking). The period $2012-2013$ to the period 2015 - 2016, the scores of Efficiency enhancers reduced, getting 4.0 points. The ranking position was remarkably unchangeable. This assessment is suitable for Vietnam's macroeconomic environment and socioeconomic situation in the period $2011-2015$ when the economy was faced with difficulties because of the growth decline, growth model instability, enterprises' inefficient operations and slow efforts for the economic structural change. In AEC, Vietnam's Efficiency enhancers have higher scores and rankings than Myanmar's (3.2 points; $131^{\text {st }}$ ranking), Laos' (4.4 points; $104^{\text {th }}$ ranking), Cambodia's (3.7 points; $97^{\text {th }}$ ranking), Brunei's (3.9 points; $87^{\text {th }}$ ranking). However, they are lower than Philippines' $\left(4.2\right.$ points; $58^{\text {th }}$ ranking $)$, Indonesia's 94.4 points; $49^{\text {th }}$ ranking), Thailand's $\left(4.6\right.$ points; $37^{\text {th }}$ ranking), Malaysia's (5.0 points; $24^{\text {th }}$ ranking) and Singapore's (5.7 points; $2^{\text {nd }}$ ranking). In the
Report 2016 - 2017, Vietnam's ranking has improved (in the first-half position of the ranking list), but it's still at the low level and there are many limitations for indicators of this group.

Firstly, the indicator which has the lowest score and ranking in Vietnam's Efficiency enhancers in the Report 2016 - 2017 is "Technological readiness" ( $3.5 ; 92)$. Compared with the previous years, this indicator improves, but is unstable (see Table) and is lower than the period $2010-2011$ (3.6; 65). The limitations of this indicator are availability of latest technology (108th ranking out of 138 surveyed countries), Firm-level technology absorption (78th ranking out of 138 surveyed countries), FDI and technology transfer (83rd ranking out of 138 surveyed countries), etc. These factors are directly related to enterprises' productivity in the economy. According to the latest report of the Asian Productivity Organization (APO, 2015), Vietnam's labor productivity in 2013 (quoted by PPP, price 2011) was equal to $6.89 \%$ of Singapore, $16.7 \%$ of Malaysia, $34.29 \%$ of Thailand, $38.3 \%$ of Indonesia, $53.50 \%$ of Philippines, equal to Lao's and higher than Myanmar's and Thailand's. Vietnam's labor productivity is only equal to $43.3 \%$ of ASEAN's average labor productivity. 
(Unit: Thousand USD)

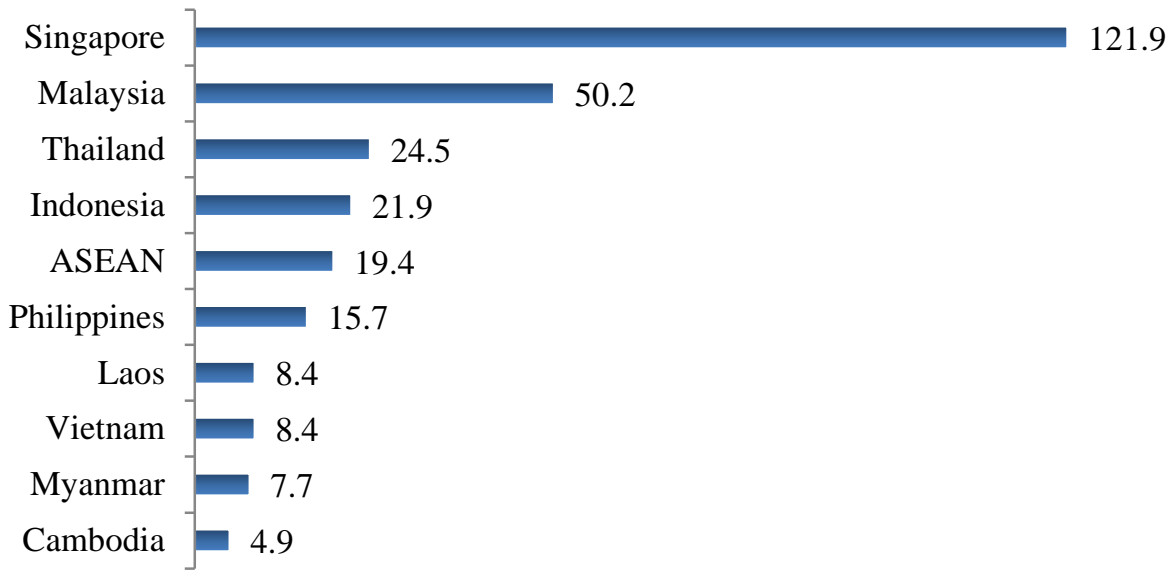

Figure 1. ASEAN nations' labor productivity in 2013 (GDP quoted by fixed price 2011, PPP) Source: APO Productivity Database 2015; page 62

Secondly, Vietnam's Higher education and training ranks below average in the WEF's assessment. The Report 2016 - 2007 shows that this indicator increases 0.3 points and 12 positions in comparison with the Report 2015 2016. This is just because of the improvement of enrollment rates of secondary and tertiary education as well as quality of math and science education. However, the indicator only ranks $83^{\text {rd }}$ out of 138 surveyed countries and is a lot lower than indicators of the countries in AEC, such as Brunei (4.5 points; $65^{\text {th }}$ ranking), Thailand (4.5 points; $62^{\text {nd }}$ ranking) and Singapore (6.3 points; $1^{\text {st }}$ ranking). Vietnam's limitations of Higher education and training are due to laggings (i) Quality of the educational system (3.6 points; $76^{\text {th }}$ ranking); (ii) Quality of management schools $\left(3.4\right.$ points; $122^{\text {nd }}$ ranking): (iii) Local availability of research and training services (3.7 points; $110^{\text {th }}$ ranking).

Thirdly, Vietnam's Financial market development in the Report 2016 - 2017 improves considerably in comparison with the previous years about the score and ranking (3.9 points; $78^{\text {th }}$ ranking), but is lower than the periods $2010-2011$ (4.2 points; $65^{\text {th }}$ ranking) and $2011-2012$ (4.0 points; $73^{\text {rd }}$ ranking). The bad debt and potential instabilities of Vietnam banking system from 2011 till now have been the causes of decline according to the WEF's assessment on the Financial market development. The latest information from Vietnam State Bank shows that until June, 2016 the bad debt of Vietnam banking system was $2.6 \%$. However, this rate did not include the bad debt which was "reserved" in Vietnam Asset Management Company (VAMC). Until the end of June, 2006 the accrued bad debt which VAMC bought was 241,000 billion VND, in which 32,400 billion VND was settled, obtaining $13.4 \%$.

Fourthly, Vietnam's indicators of Goods market efficiency, in the Report 2016 - 2017, are unchangeable in comparison with the previous years with 4.2 points and $81^{\text {st }}$ ranking out of 138 surveyed countries and at the second half position in the WEF's ranking list. In AEC, Vietnam only ranks higher than Philippines (4.1 points; $99^{\text {th }}$ ranking) and Myanmar (3.6 points; $130^{\text {th }}$ ranking), but lower than Cambodia (4.2 points; $76^{\text {th }}$ ranking) and Laos (4.3 points; $72^{\text {nd }}$ ranking). The limitations 
of Goods market efficiency in Vietnam are just due to Burden of customs procedures $\left(103^{\text {rd }}\right.$ ranking), Degree of customer orientation $\left(109^{\text {th }}\right.$ ranking), Prevalence of trade barriers $\left(108^{\text {th }}\right.$ ranking), Procedures and Time which are required to start a business $\left(116^{\text {th }}\right.$ and $103^{\text {rd }}$ rankings).

Fifthly, one of the two indicators which are at the first half position of the ranking list is Labor market efficiency. In the Report 2016 2017, this indicator gets 4.3 points and ranks $63^{\text {rd }}$ out of 138 surveyed countries, which is higher than Myanmar (4.2 points; $73^{\text {rd }}$ ranking), Thailand (4.2 points, $71^{\text {st }}$ ranking), Philippines (4.0 points; $86^{\text {th }}$ ranking) and Indonesia (3.8 points; $108^{\text {th }}$ ranking). The limitations of Labor market efficiency in Vietnam at present are Country capacity to retain and attract talent, Flexibility of wage determination and Reliance on professional management. In the recent years, the indicators of Labor market efficiency in Vietnam have been going down: The periods 2012 - 2013 (4.5 points; $51^{\text {st }}$ ranking), 2013 2014 (4.4 points; 56 ${ }^{\text {th }}$ ranking), $2014-2015$ (4.4 points; $49^{\text {th }}$ ranking), $2015-2016$ (4.4 points; $52^{\text {nd }}$ ranking), 2016 - 2017 (4.3 points; $63^{\text {rd }}$ ranking), and Vietnam's labor market has negatively been affected by the state of growth decline, instability of macroeconomic environment, decrease of competitive ability of domestic enterprises and ineffective quality of labor force.

Sixthly, in Efficiency enhancers, the indicator Market size is assessed best by the WEF, reflecting the development potential of market and purchasing power in Vietnam. The Report 2016 - 2017 shows that Vietnam's market size gets 4.8 points, ranks $32^{\text {nd }}$ out of 138 surveyed countries, is higher than countries', such as Singapore (4.7 points, $37^{\text {th }}$ ranking), Cambodia (3.3 points; $86^{\text {th }}$ ranking), Laos (2.9 points; $108^{\text {th }}$ ranking), Brunei (2.7 points; $116^{\text {th }}$ ranking), and is lower than countries', such as Malaysia (5.0 points; $24^{\text {th }}$ ranking), Thailand (5.2 points; $18^{\text {th }}$ ranking), Indonesia (5.7 points; $10^{\text {th }}$ ranking). In the recent years, Vietnam's market size has continuously improved: The periods 2012 2013 (4.6 points; 32 ${ }^{\text {nd }}$ ranking), $2013-2014$ (4.6 points; $36^{\text {th }}$ ranking), $2014-2015$ (4.7 points; $34^{\text {th }}$ ranking), $2015-2016$ (4.8 points; $33^{\text {rd }}$ ranking) and $2016-2017$ (4.8 points; $32^{\text {nd }}$ ranking). Vietnam's market size is highly evaluated about the factors: Exports percentage $G D P$ ( $11^{\text {th }}$ ranking), Foreign market size $\left(25^{\text {th }}\right.$ ranking), Domestic market size ( $35^{\text {th }}$ ranking).

\subsection{Innovation and sophistication factors}

This indicator group shows the highest level in GCI, reflecting activeness and efficiency of the economy.

Table 8. Vietnam's Innovation and sophistication factors

\begin{tabular}{|l|l|l|l|l|l|l|l|l|l|l|l|}
\hline & \multicolumn{2}{|c|}{$2012-2013$} & \multicolumn{2}{c|}{$2013-2014$} & \multicolumn{2}{c|}{$2014-2015$} & \multicolumn{2}{c|}{$2015-2016$} & \multicolumn{2}{c|}{$2016-2017$} \\
\cline { 2 - 9 } & Score & Rank & Score & Rank & Score & Rank & Score & Rank & Score & Rank \\
\hline $\begin{array}{l}\text { Innovation and } \\
\text { Sophistication } \\
\text { factors }\end{array}$ & 3.3 & $90 / 144$ & 3.4 & $85 / 148$ & 3.4 & $98 / 144$ & 3.4 & $88 / 140$ & 3.5 & $84 / 138$ \\
$\begin{array}{l}\text { 1- Business } \\
\text { sophistication }\end{array}$ & 3.6 & 100 & 3.7 & 98 & 3.6 & 106 & 3.6 & 100 & 3.6 & 96 \\
2- Innovation & 3.1 & 81 & 3.1 & 76 & 3.1 & 87 & 3.2 & 73 & 3.3 & 73 \\
\hline
\end{tabular}

Source: The Global Competitiveness Report 2016 - 2017

\section{Trang 138}


Table 9. AEC's Innovation and sophistication factors 2016-2017

\begin{tabular}{|c|c|c|c|c|c|c|c|}
\hline \multirow[t]{2}{*}{ No } & \multirow[t]{2}{*}{ Country } & \multicolumn{2}{|c|}{$\begin{array}{c}\text { Innovation and } \\
\text { sophistication factors }\end{array}$} & \multicolumn{2}{|c|}{$\begin{array}{l}\text { Business } \\
\text { sophistication }\end{array}$} & \multicolumn{2}{|c|}{ Innovation } \\
\hline & & Score & Rank & Score & Rank & Score & Rank \\
\hline 1 & Brunei & 3.5 & 78 & 3.7 & 84 & 3.3 & 78 \\
\hline 2 & Cambodia & 3.2 & 118 & 3.5 & 114 & 2.8 & 118 \\
\hline 3 & Indonesia & 4.2 & 32 & 4.3 & 39 & 4.0 & 31 \\
\hline 4 & Laos & 3.4 & 93 & 3.7 & 92 & 3.1 & 95 \\
\hline 5 & Malaysia & 4.9 & 20 & 5.2 & 20 & 4.7 & 22 \\
\hline 6 & Myanmar (*) & 2.7 & 134 & 2.9 & 135 & 2.5 & 132 \\
\hline 7 & Philippines & 3.8 & 53 & 4.1 & 52 & 3.4 & 62 \\
\hline 8 & Singapore & 5.3 & 12 & 5.2 & 19 & 5.3 & 9 \\
\hline 9 & Thailand & 3.8 & 47 & 4.3 & 43 & 3.4 & 54 \\
\hline 10 & Vietnam & 3.5 & 84 & 3.6 & 96 & 3.3 & 73 \\
\hline
\end{tabular}

Source: The Global Competitiveness Report 2016 - 2017

In the Report 2016 - 2017, the indicator group of Innovation and sophistication factors in Vietnam gets 3.5 points, ranks $84^{\text {th }}$ out of 138 surveyed countries and increases 0.1 point and 10 positions in comparison with the period 2015 - 2016. In the recent years, this indicator has had an increasing trend, reflecting the improvement of technological innovation, the expansion of cooperation and product publicity, etc. However, this indicator has the lowest point and ranking among Vietnam's 3 GCI groups and is at the below average level in the WEF's ranking list. It ranks $7^{\text {th }}$ in AEC after Brunei (3.5 points; $78^{\text {th }}$ ranking), Philippines (3.8 points; $53^{\text {rd }}$ ranking), Thailand (3.8 points; $47^{\text {th }}$ ranking), Indonesia (4.2 points; $32^{\text {nd }}$ ranking), Malaysia (4.9 points; $20^{\text {th }}$ ranking), Singapore (5.3 points; $12^{\text {th }}$ ranking) and only before Laos (3.4 points; $93^{\text {rd }}$ ranking), Cambodia $\left(3.2\right.$ points; $118^{\text {th }}$ ranking), Myanmar (2.7 points; $134^{\text {th }}$ ranking). Looking at the 2 pillars of this indicator group, we can realize Vietnam's innovation and development capacity.

Firstly, Vietnam's Business sophistication in the Report 2016 - 2017 gets 3.6 points and ranks $96^{\text {th }}$ ranking out of 138 survey countries.
In $\mathrm{AEC}$, this indicator is only higher than Cambodia's (3.5 points; $114^{\text {th }}$ ranking) and lower than Laos' (3.7 points; $92^{\text {nd }}$ ranking). The limitations of this indicator at present are due to (i) Local supplier quality (3.7 points; $109^{\text {th }}$ ranking), (ii) Nature of competitive advantage (3.1 points; $92^{\text {nd }}$ ranking), (iii) Value chain breadth (3.3 points; $109^{\text {th }}$ ranking), (iv) Extent of marketing (4.1 points; $99^{\text {th }}$ ranking), and (v) Willingness to delegate authority (3.3 points; 111 st ranking). These criteria are very important in enterprise activities and directly relevant to the business environment quality.

Secondly, in the Report 2016 - 2017, Vietnam's Innovation gets 3.3 points and ranks $73^{\text {rd }}$ ranking among 138 surveyed countries. In $\mathrm{AEC}$, this indicator is only higher than Brunei's (3.3 points; $78^{\text {th }}$ ranking), Laos' (3.1 points; $95^{\text {th }}$ ranking), Cambodia's (2.8 points; $118^{\text {th }}$ ranking). Most of the important criteria of this indicator have below average ranks: Capacity for innovation ( $79^{\text {th }}$ ranking), Quality of scientific research institutions ( $98^{\text {th }}$ ranking), University-industry collaboration in R\&D ( $79^{\text {th }}$ ranking), Availability of scientists and engineers $\left(84^{\text {th }}\right.$ ranking). This assessment is suitable for the evaluation of experts on 
training quality assessment, and scientific staff at universities, institutions in Vietnam now.

\section{DISCUSSIONS \& RECOMMENDATIONS}

Vietnam's GCI analysis in the recent years, in comparison with nations in AEC has given the above results, can generalize Vietnam's economic position in the region and also gives discussions relevant to the content we wrote in the introduction.

Firstly, Vietnam belongs to the group of 4 countries whose GCI rankings are the lowest in AEC (Vietnam, Laos, Cambodia and Myanmar). This is suitable for Vietnam's present economic position in the region. Further lagging potential of Vietnamese economy given at the Mid-term review meeting of Vietnam Communist Party (Course VII) at the end of year 1993 has been a regular worry. Although the economic gap between Vietnam and more developed countries in the region are shorten for some criteria, it is still rather big. Moreover, some criteria of economic development and competitiveness of the countries which have low rankings, such as Laos, Cambodia have started to surpass Vietnam's. Recently, the efforts of innovation and improvement of Myanmar's economy has had a sign of going up in Southeast Asia. The position of Vietnam's economy at present cannot really be 'deserved' with its advantages of geo-politics, natural and human resources as Lee Kuan Yew stated.

Secondly, the indicators which have the most low scores and rankings of Vietnam are Institutions, Infrastructure, Macroeconomic environment (Group 1), Labor market efficiency, Financial market development, Technological readiness (Group 2), Business sophistication and Innovation (Group 3). These are the disadvantages which still have existed in Vietnam's economy for many years. And these are also the major causes resulting in limitations and weaknesses of Vietnam's present economy. In AEC, dynamic economies of Singapore, Malaysia, Thailand, etc. have high scores and rankings at the pillars of GCI, which make a competitive and effectively developed environment of leading economies in Southeast Asia.

Thirdly, the analysis of Vietnam's GCI shows that the pillars ranking the lowest and having the furthest distance from many countries in AEC are Institutions, Business sophistication and Innovation. They are just the pillars of: State economy, State economy and Private economy. In 5 years from 2011 to 2015, the Communist Party and Government of Vietnam exactly realized the laggings of economy, which were caused by distributing and using resources inefficiently. However, the major cause is just Institutions. Therefore, the head of Government at that time gave sound judgments and political determinants. It was "There cannot be competitive capacity without a high-quality institution and a modern national management system." and "It's time for us to have more driving forces to recover the rapid growth impetus and sustainable development. That resource of driving forces must come from new institutions and promotion of human rights." (Nguyen Tan Dung, 2014) . However, the efforts to reform the institutions for the past 5 years haven't yet made as expected and encountered many obstacles and laggings. The sluggish in reforming institutions has not positively affected the macroeconomic environment and enterprise activities.

Fourthly, the desire to build up a propitious country with a deserved position in the region is the desire of many generations of Vietnamese people inside and outside the country. Recently, the Vietnamese government and the World Bank have issued an important

\section{Trang 140}


report about Vietnam with the title "Vietnam 2035: Toward Prosperity, Creativity, Equity and Democracy" (March, 2016), in which there is a rememberable extract: "Up to 2035, with 60 years from the country unification day, Vietnam has the desire to become a country with an industrialized and modernized economy, catches up with the economies in Southeast Asia completing the transition to become a highly average-income or highincome country. This desire gets stronger to see the outstanding achievements of nations, such as Korea, Taiwan, Singapore, Malaysia and China with worries about slagging forever." (The World Bank \& the Ministry of Planning and Investment of Vietnam, 2016 ). According to the Report, the criteria to complete industrialization and modernization are (The World Bank \& the Ministry of Planning and Investment of Vietnam, 2016):

GDP per capita gets over 18,000USD (PPP, price 2011).

Suburbanization rate gets over $50 \%$.

Industry and services account for over $90 \%$ GDP and over 70\% laborers work at industrial and service zones.

The contribution proportion of private economy to GDP is at least $80 \%$.

Human development index gets over 0.7.

The above desire is based on science and practice.

Fifthly, in order to make the desire come true, solutions to improve the competitive capacity, promote the economic growth and development, enhance the economic position in the region and the world step by step, it's necessary to:

- Exploit the location, strength about Vietnam's geo-politics, natural and human resources in the international economic integration, especially AEC and TPP integrations. The strengths of Vietnam which need emphasizing at present are (i) Vietnam's strategic geographical position in Southeast Asia and Pacific Asia; (ii) The strength about natural resources of land, forests, seas in which the tourism natural resource not yet exploited at a suitable and effective level needs to be emphasized; (iii) Vietnam's cultural and traditional values need considering to be the strength and advantage in the international integration, which is successfully exploited and implemented by the countries in the region, such as Singapore, Malaysia and Thailand.

- Improve the macroeconomic environment and institution quality is basic, urgent and the solution which has breakthrough and cannot be later in Vietnam now. The meaningfully decisive issue is to change the awareness and determination into the specific action of the whole politic system, apparatuses of the Party, National Congress and Government. These are just core solutions to enhance the investment business environment, activeness and efficiency in the economic operation.

- Have the mechanism and way of effective human resource division to improve the competitive capacity at levels of nation, industry and enterprise. The present breakthrough is to develop the private sector, which is regarded as the basic motivation and determined for the economic prosperity. The performance of "tectonic government" has recently created a new advantageous condition motivating enterprises' efforts and selfconfidence in their business startup and development. This is the practical lesson which successful countries in the economic development have carried out efficiently.

- Improve the competitive capacity of 
economy. Actually, the decisive factor must be to improve productivity. Developing human resources and strengthen investment in research and deployment are the two basic factors to improve the competitive capacity of enterprises and economy. The breakthrough to improve the quality of human resources and research deployment investment, in our opinion, needs to improve the efficiency of labor market, science and technology market and financial market. Once markets are established completely and sound about 'business place', 'business law', the resources will be circulated and used effectively. This is the best and cheapest way to adjust the structures of training, enterprise investment and economy.

- With all the solutions, in our opinion, the meaningful decisive factor is still thinking innovation, especially critical thinking. The critical thinking innovation is the solution to deal with the present obstacle in the economy, such as the decisive role of state economy, the level limit of land use in agriculture, anticorruption and interest group prevention, downsizing and professionalism of state apparatus.

\section{CONCLUSION}

"If there is a number 1 position in Southeast Asia, it must be worth belonging to Vietnam". This statement by Lee Kuan Yew is really a lot further than the reality of Vietnamese economy. Yet if considered in the future, this judgment is reasonable. The first necessity for Vietnamese people is the desire for success which they obtained to bring dependence and freedom for the country. The industrialization, modernization and desire to get prosperity depend on not only determination but also ways, steps and breakthroughs at specific points of time. In the present time, improving the competitive capacity by promoting institutions, stabilizing the macroeconomic environment, increasing the investment in research and deployment, encouraging the development of private sector must be an urgent requirement and have a breakthrough meaning to the economy. When the business environment improves, national resources are divided and used effectively and enterprises' competitive capacity enhances better, the economic position will be raised highly and Vietnamese people's desire will have the basis to come true. 


\section{Vị thế của Việt Nam trong Cộng đồng kinh tế ASEAN (AEC) qua phân tích chỉ số năng lực cạnh tranh toàn cầu $(\mathrm{GCI})$}

- $\quad$ Nguyễn Chí Hải

- Trà Văn Trung

Trường Đại học Kinh tế - Luật, ĐHQG HCM - Email: hainc@uel.edu.vn

\section{TÓM TẮT}

Chi số năng lục cạh tranh toàn cầu (GCI) là một căn cứ đáng tin cậy để đánh giá trình độ và năng lực đổi mói và phát triển đối với các nền kinh tế. Mục tiêu nghiên cúu này là trên cơ sở phân tích GCI của Việt Nam trong việc so sánh với các nước thuộc $A E C$, để tù đó "định vị" vị trí của nền kinh tế Việt Nam trong khu vục. Kết quả nghiên cứu chỉ ra rằng: (i) Có mối quan hệ tuoong đồng giũa GCI của Việt
Nam với vị trí của nền kinh tế Việt Nam trong AEC; (ii) Nhũng hạn chế GCI Việt Nam cũng chính là nhũng nguyên nhân của nhũng hạn chế, bất cập trong nền kinh tế Việt Nam hiện nay; (iii) Khâu đột phá đối với phát triển kinh tế Việt Nam, rút ngắn khoảng cách kinh tế Việt Nam đối với các nước trong AEC là cần có các giải pháp nâng cao năng lục cạnh tranh của nền kinh tế.

Tù khóa: Vị trí kinh tế Việt Nam trong AEC; chỉ số năng lực cạnh tranh toàn cà̀u của Việt Nam.

\section{REFERENCES}

[1]. Acemoglu, D. \& Robinson, J. A. (2013). Why Nations Fail: The Origins of Power, Prosperity, and Poverty. Youth Publisher.

[2]. An Huy (2016). Vietnam decreases 4 positions of the Global Competitiveness. Retrieved from http://vneconomy.vn/thegioi/viet-nam-giam-4-bac-nang-luc-canhtranh-toan-cau-201609291029974 7.htm.

[3]. Ministry of Foreign Affairs - ASEAN Department (2015). An introduction to ASEAN Economic Community. Retrieved from http://asean.mofa.gov.vn/thongtin/10/khai-quat-ve-cong-dong-asean.html.

[4]. Asian Productivity Organization (2015). APO Productivity Databook. Retrieved from http://www.apotokyo.org/publications/wp-
content/uploads/sites/5/APO-ProductivityDatabook-2015.pdf.

[5]. Cam Ha (January 16, 2007). Mr Ly Quang Dieu returned to Vietnam. Retrieved from http://vietbao.vn/Xa-hoi/Ong-Ly-QuangDieu-tro-lai-VN/70074874/157/.

[6]. Doan Van Doi (2015). The Analysis of Vietnam's Global Competitiveness Index in the Period 2010 - 2014. Can Tho University.

[7]. Nguyen Chi Hai (2014). Competitive Capacity Improvement - An Urgent Requirement for Vietnam's Present Economy. Journal of Human Development, 4, 34-37.

[8]. Nguyen Ngoc Tran (2016, October 14). What do You Realize through Vietnam's 
Global Competitiveness Index?. Retrieved from

http://daibieunhandan.vn/default.aspx?tabid $=75 \&$ NewsId $=379799$.

[9]. Nguyen Tan Dung (2014, January 1). Re: Perfecting Institutions, Promoting Human Rights, Getting Good Tasks of Year 2014, Creating the Foundation for Rapid and Sustainable Development. [The New Year message by the Prime Minister]. Retrieved from http://vov.vn/chinh-tri/hoan-thien-theche-phat-huy-dan-chu-phat-trien-ben-vung303787.vov.

[10]. Ha Thu (2016). Vietnam's Global Competitiveness Ranking Go down. Retrieved from http://kinhdoanh.vnexpress.net/tin-tuc/vi$\mathrm{mo} /$ viet-nam-tut-hang-nang-luc-canh-tranhtoan-cau-3475698.html.

[11]. The World Bank \& the Ministry of Planning and Investment of Vietnam. (2016). Vietnam 2035: Toward Prosperity, Creativity, Equity and Democracy. An overview report (pp. 20-22).

[12]. Vuong Dinh Hue (2016). Improving the Competitive Capacity of Nation in the Context of International Integration. Retrieved from http://vuongdinhhue.chinhphu.vn/Home/Na ng-cao-nang-luc-canh-tranh-quoc-giatrong-boi-canh-hoi-nhap-quocte/20164/18.vgp.

[13]. World Economic Forum (2012). The Global competitiveness Report 2012-2013. Retrieved from http://www3.weforum.org/docs/WEF_Glob alCompetitivenessReport_2012-13.pdf.

[14]. World Economic Forum (2013). The Global competitiveness Report 2013-2014. Retrieved from http://www3.weforum.org/docs/WEF_Glob alCompetitivenessReport_2013-14.pdf.

[15]. World Economic Forum (2014). The Global competitiveness Report 2014-2015. Retrieved from http://www3.weforum.org/docs/WEF_Glob alCompetitivenessReport_2014-15.pdf.

[16]. World Economic Forum (2015). The Global competitiveness Report 2015-2016. Retrieved from http://www3.weforum.org/docs/WEF_Glob alCompetitivenessReport_2015-16.pdf.

[17]. World Economic Forum (2016). The Global competitiveness Report 2016-2017. Retrieved from http://www3.weforum.org/docs/WEF_Glob alCompetitivenessReport_2016-17.pdf. 